\title{
CRINGING AT MYTHS OF BLACK SEXUALITY*
}

\author{
Charles R. LAWRENCE III**
}

On Friday evening [October 11, 1991], Clarence Thomas called the Judiciary Committee hearings inquiring into Anita Hill's charges of sexual harassment a "high-tech lynching of an uppity black man." On Saturday, he called himself the victim of bigoted "racial attitudes about black men and their views on sex." Is this another confirmation conversion? Has this man who has scolded fellow blacks for complaining about racism suddenly discovered that he is still black? Is this the same man who invoked the racist stereotype of the black welfare queen to wrongly accuse his own sister?

I would like to believe that Judge Thomas has finally learned that he will never be free of racist stereotypes until the least of us is free. I would like to believe that his invocation of the most vivid symbols of racial oppression is more than a desperate attempt to divert attention from the serious and credible charges that have been leveled against him. I would like to believe that he is concerned not just for himself but for all of us. Los Angeles Congresswoman Maxine Waters echoed the sentiments of many of us when she spoke skeptically of this man who has so faithfully served a President who has made race-baiting his stock in trade.

Whatever his motivations might be, Thomas has called the nation's attention to one of its oldest and ugliest stories. This is a story of stereotypes about race and sex that are deeply embedded in the American psyche. It is a story of violence against black men and women motivated and justified by those stereotypes-a history of black men lynched and castrated, of black women raped-with no fear of consequences.

African-Americans cannot help but cringe as we hear the lurid details of Anita Hill's account of her harassment. We cringe because we know that the myths of black sexuality are alive and well in America.

* This Essay originally appeared in the LOS ANGeles TiMEs, Oct. 15, 1991, at B7. Reprinted with permission.

* Professor of Law, Stanford University; Visiting Professor of Law at the University of Southern California Law Center 1991-92. 
We cringe because we know that when this story is told about one black man, all black men are implicated. White America will hear this story not just as a lesson about the ubiquity of sexual harassment in the workplace. They will hear it as a story about oversexed black men.

Yet another story is being told as white America watches this Washington soap opera. This is the story of the way in which Americans have turned a blind eye to the rape of black women by propagating the myth that black women had no right to refuse the sexual advances of any man. When the man on the street says, "I don't believe Hill's story," it is in part because he believes the old, oft-told story of "unchaste" black women. When Senator Orrin Hatch charges that her experience is the fantasy of a spurned woman, he is evoking this myth. When he implies that she tried to seduce Thomas by inviting him into her apartment, and when he reads the most lurid language in her account over and over again, all the while protesting his disgust, he is conjuring up these same racist images of the wanton black woman.

An integral part of this story has been the historical use of violence against black women as a way to deliver a message of white domination to black men: "You are not a man in this patriarchal world if you do not control your women, if you cannot protect your women from white men, if you do not have control over and access to your women's sexuality as we do."

There is a third story here that is perhaps the most difficult for those of us in the African-American community to talk about. It is the story of black male violence against and degradation of black women. This is a story of our own internalization of racist myths, a story of black men taking the anger that wells up within us when we are humiliated and degradated by whites and turning it on the women within our own families and communities. It is a story that leads many in our community to believe Anita Hill even as we wish that we could say, "This cannot be true." There has been an unwritten code of silence that says we must not speak about this story outside of our communities because white men will use it against us. This is why so many blacks who believe Hill's story continue to wish that it had never been told.

The drama that is being played out in the Senate is much more than an inquiry into the credibility of two individuals. It is more than an important lesson about sexual harassment in the workplace. For black Americans, it raises the most difficult of dilemmas. How do we simultaneously fight the mutually reinforcing oppressions of racism and sexism in society and in our own community? How do we respond when these 
issues must be spoken to in the glare of television lights and under the pressure of newspaper deadlines? How do we talk about what is most difficult to talk about when the conversation about us, about who we are and what we think, is dominated by those whose primary concern is not our community's well-being?

As I've listened to folks from my community these last few terrible days, I hear anguish, hurt and anger in their voices. It is an expression of pain and dismay that seems much more genuine that the almost theatrical fury we have heard from Clarence Thomas in his new role as victim.

Judge Thomas is hoping that in taking on this victim's role he will appeal to the black community's sense of solidarity. He is trusting that in our desire to protect ourselves from racist stereotyping we will stand with him and blame Professor Hill for being the messenger who has been the bearer of the bad news. Many of us have felt, and some of us have said, "Why is she airing this dirty laundry?" But solidarity cannot mean silence. It will not serve us to fight racism by tolerating sexism within our own community.

Anita Hill is also one of our own. If her story is true, as I believe it is, she is the victim, and Clarence Thomas must not be allowed to use our collective racial victimization to blind us to that awful truth. 